\title{
An efficient protocol for in vitro regeneration from the nodal explants of Withania coagulans (Stocks) Dunal: a valuable medicinal herb
}

\author{
Pari DEHVARI-NAGAN ${ }^{1}$, Hossein ABBASPOUR ${ }^{2 *}$, Mohammad Hasan ASARE ${ }^{3}$, Sara SAADATMAND ${ }^{1}$
}

Received July 02, 2020; accepted March 16, 2021. Delo je prispelo 2. julija 2020, sprejeto 16. marca 2021.

\begin{abstract}
An efficient protocol for in vitro regeneration from the nodal explants of Withania coagulans (Stocks) Dunal: a valuable medicinal herb

Abstract: In order to develop a protocol for the effective micropropagation of the important medicinal plant Withania coagulans (Stocks) Dunal, the effects of different concentrations and combinations of growth regulators on the nodal explants in two independent experiments were investigated. For shooting, a MS medium fortified with different concentrations and combinations of IBA $\left(0.01,0.1\right.$ and $\left.0.5 \mathrm{mg} \mathrm{l}^{-1}\right)$, BA $(0.5,1$ and 2 $\left.\mathrm{mg} \mathrm{l}^{-1}\right)$, Kin $\left(0.5\right.$ and $\left.1 \mathrm{mg} \mathrm{l}^{-1}\right)$, PG $\left(0.5 \mathrm{mg} \mathrm{l}^{-1}\right)$ and GA $(0.5 \mathrm{mg}$ $\left.1^{-1}\right)$ was used and the highest shooting response, shoot number and shoot length were obtained in the MS + IBA $\left(0.01 \mathrm{mg} \mathrm{l}^{-1}\right)+$ BA $\left(0.5 \mathrm{mg} \mathrm{l}^{-1}\right)+$ PG $\left(0.5 \mathrm{mg} \mathrm{l}^{-1}\right)+\mathrm{GA}\left(0.5 \mathrm{mg} \mathrm{l}^{-1}\right)$ treatment. In the second experiment, the effect of MS supplemented with different combinations and concentrations of $\operatorname{IBA}(0.1,0.5,1$ and $\left.2 \mathrm{mg} \mathrm{l}^{-1}\right)$, NAA $\left(0.1\right.$ and $\left.1 \mathrm{mg} \mathrm{l}^{-1}\right)$ and PG $\left(1 \mathrm{mg} \mathrm{l}^{-1}\right)$ on rooting of the nodal explants was investigated, which showed that the highest rooting response (\%) was observed in the MS fortified with NAA $\left(0.1 \mathrm{mg} \mathrm{l}^{-1}\right)$, NAA $\left(1 \mathrm{mg} \mathrm{l}^{-1}\right)$, NAA $\left(0.1 \mathrm{mg} \mathrm{l}^{-1}\right)+\mathrm{PG}$ $\left(1 \mathrm{mg} \mathrm{l}^{-1}\right)$, and NAA $\left(1 \mathrm{mg} \mathrm{l}^{-1}\right)+$ PG $\left(1 \mathrm{mg} \mathrm{l}^{-1}\right)$ treatments, as well as the highest number of roots at NAA $\left(0.1 \mathrm{mg} \mathrm{l}^{-1}\right)$ and the highest root length at IBA $\left(1 \mathrm{mg} \mathrm{l}^{-1}\right)$. Our findings highlight a complete micropropagation method for $W$. coagulans from the nodal explant that can make a significant contribution to the development of $W$. coagulans material for medical applications.

Key words: Withania coagulans; micropropagation; in vitro; nodal explant; phloroglucinol
\end{abstract}

Učinkovit protocol za in vitro regeneracijo nodijskih izsečkov vrste Withania coagulans (Stocks) Dunal, cenjene zdravilne rastline

Izvleček: Z namenom izboljšanja protokola za učinkovito mikropropagacijo pomembne zdravilne rastline (Withania coagulans (Stocks) Dunal) so bili preučevani učinki različnih koncentracij in kombinacij rastnih regulatorjev na izsečkih kolenc $\mathrm{v}$ dveh neodvisnih poskusih. Za razvoj poganjkov je bilo uporabljeno MS gojišče, obogateno $\mathrm{z}$ različnimi koncentracijami in kombinacijami IBA $\left(0,01 ; 0,1\right.$ in $\left.0,5 \mathrm{mg} \mathrm{l}^{-1}\right)$, BA (0,5; 1 in $\left.2 \mathrm{mg} \mathrm{l}^{-1}\right)$, Kin $\left(0,5\right.$ in $\left.1 \mathrm{mg} \mathrm{l}^{-1}\right)$, PG $\left(0,5 \mathrm{mg} \mathrm{l}^{-1}\right)$ in GA $(0,5$ $\left.\mathrm{mg}^{-1}\right)$. Največji odziv $\mathrm{v}$ rasti poganjkov, $\mathrm{v}$ njihovem številu in dolžini je bil dosežen pri obravnavanju MS + IBA $\left(0,01 \mathrm{mg} \mathrm{l}^{-1}\right)$ + BA $\left(0,5 \mathrm{mg} \mathrm{l}^{-1}\right)+\mathrm{PG}\left(0,5 \mathrm{mg} \mathrm{l}^{-1}\right)+\mathrm{GA}\left(0,5 \mathrm{mg} \mathrm{l}^{-1}\right)$. V drugem poskusu je bil preučevan učinek MS z dodatkom različnih koncentracij in kombinacij IBA $\left(0,1 ; 0,5 ; 1\right.$ in $\left.2 \mathrm{mg} \mathrm{l}^{-1}\right)$, NAA $(0,1$ in $\left.1 \mathrm{mg} \mathrm{l}^{-1}\right)$ in PG $\left(1 \mathrm{mg} \mathrm{l}^{-1}\right)$ na zakoreninjenje nodijskih izsečkov, pri čemer je bil dosežen največji odziv zakoreninjenja (\%) pri obravnavanju MS obogatenim z NAA $\left(0,1 \mathrm{mg} \mathrm{l}^{-1}\right)$, NAA (1 mg $\left.\mathrm{l}^{-1}\right)$, NAA $\left(0,1 \mathrm{mg} \mathrm{l}^{-1}\right)+$ PG $\left(1 \mathrm{mg} \mathrm{l}^{-1}\right)$, in NAA $\left(1 \mathrm{mg} \mathrm{l}^{-1}\right)+\mathrm{PG}$ $\left(1 \mathrm{mg} \mathrm{l}^{-1}\right)$. Največje število korenin je bilo pri obravnavanju $\mathrm{s}$ NAA $\left(0,1 \mathrm{mg} \mathrm{l}^{-1}\right)$, največja dolžina korenin pa pri obravnavanju z IBA ( $\left.1 \mathrm{mg} \mathrm{l}^{-1}\right)$. Izsledki raziskave pojasnjujejo celotno metodo mikropropagacije vrste $W$. coagulans iz izsečkov kolenc, kar je pomemben prispek $\mathrm{k}$ vzgoji sadilnega materiala te vrste za uporabo v zdravstvu.

Ključne besede: Withania coagulans; mikropropagacija; in vitro; nodijski izsečki; floroglucinol

1 Islamic Azad University, Faculty of Biological Sciences, Science and Research Branch, Department of Biology, Tehran, Iran

2 Islamic Azad University, Faculty of Biological Sciences, North Tehran Branch, Department of Biology, Tehran, Iran

3 Research Institute of Forests and Rangelands, Tehran, Iran

${ }^{*}$ Correspondence author: abbaspour75@yahoo.com 


\section{INTRODUCTION}

Withania coagulans Dunal is one of the most important species in the Solanaceae family, growing mainly in the eastern Mediterranean to South Asia, including Iran, Afghanistan, Pakistan and India. W. coagulans is widely used due to its numerous medicinal properties such as hypo-lipidemic, cardiovascular, hepato-protective, antihyperglycemic, anti-diabetic and anti-tumor (Haq et al., 2013; Maurya \& Akanksha, 2010). W. coagulans fruits are used in cheese production due to their ability to coagulate the milk. The numerous medicinal properties of $W$. coagulans are mainly due to the compounds of withanolides that are naturally synthesized by the plant (Haq et al., 2013; Chen et al., 2011). Due to the accumulation of the medicinal compound withanolide $\mathrm{A}$ in the aboveground parts of $W$. coagulans in comparison with the root of W. somnifera (L.) Dunal, indicates the economical and easy harvesting of withanolides (Rathore et al., 2016). Due to the lack of proper cultivation practices, $W$. coagulans plants are harvested from wild, which represents a threat to the natural diversity of its germplasm. Reducing the chance of seed setting due to self-incompatibility and polygamous-dioecious nature of flowers reduces the rate of natural regeneration that cannot meet the rate of exploitation (Rathore et al., 2012; Gilani et al., 2009).

Various factors, such as reproductive failure, habitat disturbances, hostile environmental factors and overexploitation, pose a serious threat to valuable medicinal plants, which may expose them to complete extinction (Gerami et al., 2018; Ghorbani et al. 2018). Therefore, collecting plants from nature is not a viable way to meet commercial requirements, and it is important to establish the appropriate strategies to meet the needs (Ghorbani et al. 2019). In vitro culture is one of the biotechnology powerful tools that can be effective in the propagation of genetically uniform plants from the elite lines in large numbers, which can eliminate the need to collect medicinal plants from wild (Ghasemi-Omran et al. 2021). Hence the propagation of endangered or rare plants using in vitro culture can help maintain germplasms and prevent extinction (Rathore et al., 2016). Furthermore, due to the propagation of genetically uniform plants by in vitro culture, it allows the accurate study of stress tolerance and the regulation of secondary metabolites between different treatments, which could have potential application in elite breeding lines. A simple and efficient method for in vitro propagation of $W$. coagulans is a necessity for its sustainable use in order to meet pharmaceutical requirements. It can also provide the primary needs for genetic improvement through genetic transformation, genetic restoration programs through true- to-type propagation, and phyto-pharming improvement. Therefore, in the current study, the aim was to investigate the potential of the nodal explants in order to develop an effective protocol for the in vitro propagation of Withania coagulans Dunal.

\section{MATERIAL AND METHODS}

Young, non-lignified stems of $W$. coagulans were collected from Iran (Saravan region, Sistan and Baluchestan Province). The stems were soaked in liquid detergent $\left(10 \%\left(\mathrm{vv}^{-1}\right)\right.$ Teepol) for $5 \mathrm{~min}$ after rinsing with running tap water for $30 \mathrm{~min}$. After rinsing with running tap water $(10 \mathrm{~min})$, the stems were cut into $2 \mathrm{~cm}$ segments (explants), each segment containing a node. Then, after disinfection with an $\mathrm{HgCl}_{2}(0.1 \%)$ for $5 \mathrm{~min}$ and rinsing with sterile distilled water (five times), the nodal segments were used for culture.

The explants were implanted vertically on MS medium (Murashige \& Skoog, 1962) containing agar (C, $0.8 \%)$ and sucrose $\left(\mathrm{mg} \mathrm{l}^{-1}, 3 \%\right)$ at $\mathrm{pH}$ 5.8. In order to investigate the effect of different hormonal combinations on W. coagulans shooting and rooting, the culture media were supplemented with different concentrations and combinations of growth regulators. The treatments applied for shooting and rooting are represented in Table 1 . The plant material was kept at $25 / 18^{\circ} \mathrm{C}$ with $14 \mathrm{~h}$ photoperiod and $60-80 \mu \mathrm{mol} \mathrm{m}^{-2} \mathrm{~s}^{-1}$ light intensity. After 6 weeks, the number of differentiated shoots per node, shoot length, shoot multiplication percentage, number roots per shoot, root length and rooting percentage were recorded.

For acclimatization, the rooted plants were transferred to plastic pots containing an autoclaved mixture of cocopeat, soil and sand (1:1:1) after rinsing with tap water and removing agar. To retain humidity, the pots were covered with clear plastics and kept in the tissue culture laboratory. After 10 days, the plastic cover was removed from the pots and the pots were kept at $25{ }^{\circ} \mathrm{C}$ with 16 $\mathrm{h}$ photoperiod. After 3 weeks, the plantlets were transferred to normal field conditions.

All experiments were repeated three times and the means value were calculated based on four independent replicates (Each replication contained 5 explants). Statistical analysis of the results was calculated using SAS v. 9.1.3 software and the mean comparison was carried out with a least significant difference (LSD) test (at the $5 \%$ level). 
Table 1: Treatments applied in two experiments of the induction of shooting and rooting from the nodal explants of $W$. coagulans

\begin{tabular}{|c|c|c|}
\hline & Treatments applied for shooting & Treatments applied for rooting \\
\hline $\mathrm{T} 1$ & MS (Control) & MS (Control) \\
\hline $\mathrm{T} 2$ & $\mathrm{MS}+\mathrm{IBA}\left(0.01 \mathrm{mg} \mathrm{l}^{-1}\right)+\mathrm{BA}\left(0.5 \mathrm{mg} \mathrm{l}^{-1}\right)+\mathrm{PG}\left(0.5 \mathrm{mg} \mathrm{l}^{-1}\right)$ & $\mathrm{MS}+\operatorname{IBA}\left(0.1 \mathrm{mg} \mathrm{l}^{-1}\right)$ \\
\hline T3 & $\mathrm{MS}+\mathrm{IBA}\left(0.01 \mathrm{mg} \mathrm{l}^{-1}\right)+\mathrm{BA}\left(0.5 \mathrm{mg} \mathrm{l}^{-1}\right)+\mathrm{PG}\left(0.5 \mathrm{mg} \mathrm{l}^{-1}\right)$ & $\mathrm{MS}+\mathrm{IBA}\left(0.5 \mathrm{mg} \mathrm{l}^{-1}\right)$ \\
\hline T4 & $\mathrm{MS}+\operatorname{IBA}\left(0.5 \mathrm{mg} \mathrm{l}^{-1}\right)+\mathrm{BA}\left(2 \mathrm{mg} \mathrm{l}^{-1}\right)$ & $\mathrm{MS}+\mathrm{IBA}\left(1 \mathrm{mg} \mathrm{l}^{-1}\right)$ \\
\hline T5 & $\mathrm{MS}+\operatorname{Kin}\left(0.5 \mathrm{mg} \mathrm{l}^{-1}\right)+\mathrm{BA}\left(0.5 \mathrm{mg} \mathrm{l}^{-1}\right)+\mathrm{PG}\left(0.5 \mathrm{mg} \mathrm{l}^{-1}\right)$ & $\mathrm{MS}+\mathrm{IBA}\left(2 \mathrm{mg} \mathrm{l}^{-1}\right)$ \\
\hline T6 & $\mathrm{MS}+\mathrm{PG}\left(0.5 \mathrm{mg} \mathrm{l}^{-1}\right)+\mathrm{BA}\left(1 \mathrm{mg} \mathrm{l}^{-1}\right)$ & $\mathrm{MS}+\mathrm{NAA}\left(0.1 \mathrm{mg} \mathrm{l}^{-1}\right)$ \\
\hline T7 & $\mathrm{MS}+\operatorname{Kin}\left(1 \mathrm{mg} \mathrm{l}^{-1}\right)+\mathrm{IBA}\left(0.5 \mathrm{mg} \mathrm{l}^{-1}\right)+\mathrm{BA}\left(1 \mathrm{mg} \mathrm{l}^{-1}\right)$ & $\mathrm{MS}+\mathrm{NAA}\left(1 \mathrm{mg} \mathrm{l}^{-1}\right)$ \\
\hline T8 & $\mathrm{MS}+\operatorname{IBA}\left(0.1 \mathrm{mg} \mathrm{l}^{-1}\right)+\mathrm{BA}\left(2 \mathrm{mg} \mathrm{l}^{-1}\right)$ & $\mathrm{MS}+\mathrm{IBA}\left(0.1 \mathrm{mg} \mathrm{l}^{-1}\right)+\mathrm{PG}\left(1 \mathrm{mg} \mathrm{l}^{-1}\right)$ \\
\hline T9 & $\mathrm{MS}+\mathrm{IBA}\left(0.01 \mathrm{mg} \mathrm{l}^{-1}\right)+\mathrm{BA}\left(0.5 \mathrm{mg} \mathrm{l}^{-1}\right)+\mathrm{PG}\left(0.5 \mathrm{mg} \mathrm{l}^{-1}\right)+\mathrm{GA}\left(0.5 \mathrm{mg} \mathrm{l}^{-1}\right)$ & $\mathrm{MS}+\mathrm{IBA}\left(1 \mathrm{mg} \mathrm{l}^{-1}\right)+\mathrm{PG}\left(1 \mathrm{mg} \mathrm{l}^{-1}\right)$ \\
\hline T10 & $\mathrm{MS}+\operatorname{Kin}\left(1 \mathrm{mg} \mathrm{l}^{-1}\right)+\mathrm{BA}\left(1 \mathrm{mg} \mathrm{l}^{-1}\right)+\mathrm{PG}\left(0.5 \mathrm{mg} \mathrm{l}^{-1}\right)$ & $\mathrm{MS}+\mathrm{NAA}\left(0.1 \mathrm{mg} \mathrm{l}^{-1}\right)+\mathrm{PG}\left(1 \mathrm{mg} \mathrm{l}^{-1}\right)$ \\
\hline T11 & --------- & $\mathrm{MS}+\mathrm{NAA}\left(1 \mathrm{mg} \mathrm{l}^{-1}\right)+\mathrm{PG}\left(1 \mathrm{mg} \mathrm{l}^{-1}\right)$ \\
\hline
\end{tabular}

IBA: Indole-3-butyric acid, BA: 6-Benzyladenin, PG: Phloroglucinol, Kin: Kinetin, GA: Gibberellic acid, NAA: 1-Naphthaleneacetic acid

\section{RESULTS}

In the present study, the effect of different concentrations and combinations of plant hormones (auxin, cytokinin, and gibberellin) and phenolic composition (phloroglucinol) on induction of branching in nodal explants of $W$. coagulans under in vitro conditions were investigated. The results showed that supplement of MS medium with different concentrations and combinations of IBA (0.01, 0.1 and $\left.0.5 \mathrm{mgl}^{-1}\right)$, BA $\left(0.5,1\right.$ and $\left.2 \mathrm{mgl}^{-1}\right)$, Kin (0.5 and $\left.1 \mathrm{mgl}^{-1}\right)$, GA $\left(0.5 \mathrm{mgl}^{-1}\right)$ and PG $\left(0.5 \mathrm{mgl}^{-1}\right)$ increased shooting compared to control treatment (Fig. 1). As shown in Table 2, the highest increase in the number of shoots per explant was observed in T9 treatment by $170 \%$ compared to T1 (MS medium). Furthermore, a high number of shoots per explant was also observed in T7, T4 and T3 treatments, respectively (Table 2 ). The initiation of bud break and the emergence of buds from explants were induced within 8 to 10 days in all treatments, except for T1 and T10 treatments, which began within 15 to 20 days. The highest response to nodal segments of $W$. coagulans in terms of shoot multiplication (\%) was obtained in T9 treatments. Following T9 treatment, the highest shoot multiplication was observed in T7, T2 and T3 treatments, respectively (Table 2 ). The results showed that adding different concentrations and combinations of plant hormones and phenol compound to the MS medium caused a significant increase in shoot length, so that the highest shoot length in T9 and T5 treatments was observed by $163 \%$ and $92 \%$, respectively, compared to the MS treatment alone (Table 2).

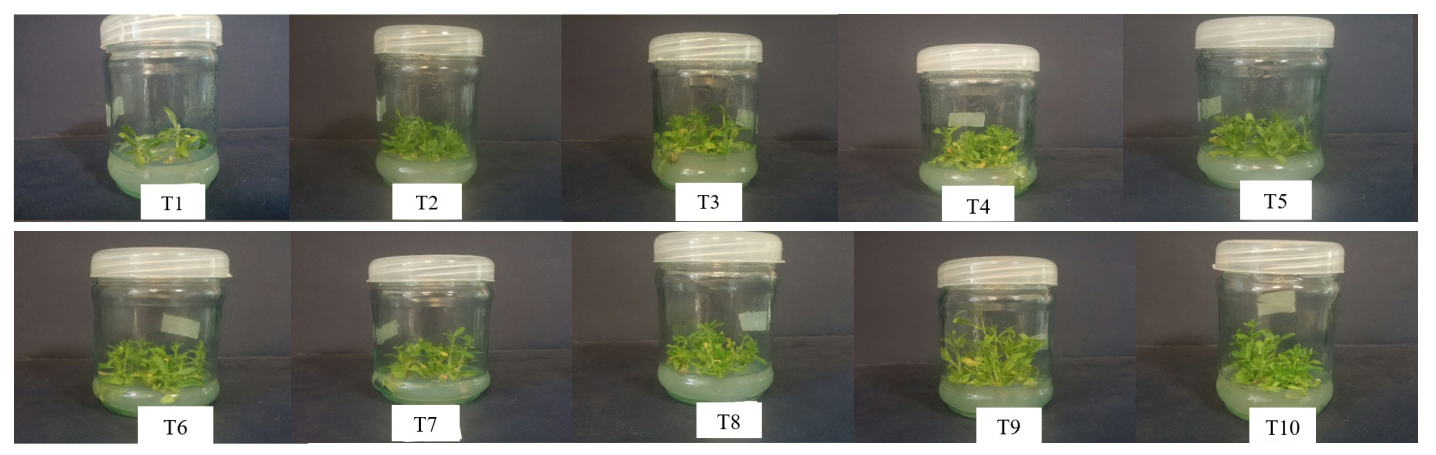

Fig. 1: The effect of different treatments on shooting from the nodal explants of $W$. coagulans in in vitro conditions. 
Table 2: The effect of different concentrations and combinations of growth regulators on shooting from the nodal explants of $W$. coagulans in in vitro conditions.

\begin{tabular}{|c|c|c|c|}
\hline Treatments & $\begin{array}{l}\text { Number of } \\
\text { shoots/nodes }\end{array}$ & $\begin{array}{c}\text { Shoot } \\
\text { multiplication (\%) }\end{array}$ & Shoot length \\
\hline T1 (MS (Control)) & $2.50 \pm 0.58 \mathrm{~cd}$ & $37.75 \pm 3.31 \mathrm{f}$ & $1.075 \pm 0.17 \mathrm{e}$ \\
\hline $\mathrm{T} 2\left(\mathrm{MS}+\mathrm{IBA}\left(0.01 \mathrm{mg} \mathrm{l}^{-1}\right)+\mathrm{BA}\left(0.5 \mathrm{mg} \mathrm{l}^{-1}\right)+\mathrm{PG}\left(0.5 \mathrm{mg} \mathrm{l}^{-1}\right)\right.$ & $4.25 \pm 0.50 \mathrm{~b}$ & $72.75 \pm 4.57 \mathrm{c}$ & $1.810 \pm 0.27 \mathrm{bc}$ \\
\hline $\mathrm{T} 3\left(\mathrm{MS}+\mathrm{IBA}\left(0.01 \mathrm{mg} \mathrm{l}^{-1}\right)+\mathrm{BA}\left(0.5 \mathrm{mg} \mathrm{l}^{-1}\right)+\mathrm{PG}\left(0.5 \mathrm{mgl}^{-1}\right)\right.$ & $4.50 \pm 0.58 \mathrm{~b}$ & $72.51 \pm 3.70 \mathrm{~cd}$ & $1.883 \pm 0.27 \mathrm{bc}$ \\
\hline $\mathrm{T} 4\left(\mathrm{MS}+\mathrm{IBA}\left(0.5 \mathrm{mg} \mathrm{l}^{-1}\right)+\mathrm{BA}\left(2 \mathrm{mg} \mathrm{l}^{-1}\right)\right.$ & $4.51 \pm 0.48 \mathrm{~b}$ & $66.50 \pm 4.43 \mathrm{~d}$ & $1.695 \pm 0.23 \mathrm{~cd}$ \\
\hline $\mathrm{T} 5\left(\mathrm{MS}+\operatorname{Kin}\left(0.5 \mathrm{mg} \mathrm{l}^{-1}\right)+\mathrm{BA}\left(0.5 \mathrm{mg} \mathrm{l}^{-1}\right)+\mathrm{PG}\left(0.5 \mathrm{mg} \mathrm{l}^{-1}\right)\right.$ & $4.25 \pm 0.57 \mathrm{~b}$ & $66.50 \pm 4.65 \mathrm{~d}$ & $2.063 \pm 0.25 b$ \\
\hline $\mathrm{T} 6\left(\mathrm{MS}+\mathrm{PG}\left(0.5 \mathrm{mg} \mathrm{l}^{-1}\right)+\mathrm{BA}\left(1 \mathrm{mg} \mathrm{l}^{-1}\right)\right.$ & $4.23 \pm 0.51 \mathrm{~b}$ & $67.51 \pm 5.51 \mathrm{~cd}$ & $1.890 \pm 0.21 \mathrm{bc}$ \\
\hline $\mathrm{T} 7\left(\mathrm{MS}+\operatorname{Kin}\left(1 \mathrm{mg} \mathrm{l}^{\mathrm{l}^{-1}}\right)+\mathrm{IBA}\left(0.5 \mathrm{mgl}^{-1}\right)+\mathrm{BA}\left(1 \mathrm{mg} \mathrm{l}^{-1}\right)\right.$ & $4.51 \pm 0.56 \mathrm{~b}$ & $79.75 \pm 4.27 \mathrm{~b}$ & $1.975 \pm 0.17 \mathrm{bc}$ \\
\hline $\mathrm{T} 8\left(\mathrm{MS}+\mathrm{IBA}\left(0.1 \mathrm{mgl}^{-1}\right)+\mathrm{BA}\left(2 \mathrm{mg} \mathrm{l}^{-1}\right)\right.$ & $3.25 \pm 0.51 \mathrm{c}$ & $51.00 \pm 4.32 \mathrm{e}$ & $1.490 \pm 0.22 \mathrm{~d}$ \\
\hline $\begin{array}{l}\text { T9 }\left(\mathrm{MS}+\mathrm{IBA}\left(0.01 \mathrm{mg} \mathrm{l}^{\mathrm{l}^{-1}}\right)+\mathrm{BA}\left(0.5 \mathrm{mg} \mathrm{l}^{-1}\right)+\mathrm{PG}\left(0.5 \mathrm{mg} \mathrm{l}^{-1}\right)+\mathrm{GA}(0.5\right. \\
\left.\mathrm{mg} \mathrm{l}^{-1}\right)\end{array}$ & $6.75 \pm 0.96 \mathrm{a}$ & $96.00 \pm 3.37 \mathrm{a}$ & $2.830 \pm 0.17 \mathrm{a}$ \\
\hline $\mathrm{T} 10\left(\mathrm{MS}+\operatorname{Kin}\left(1 \mathrm{mg} \mathrm{l}^{-1}\right)+\mathrm{BA}\left(1 \mathrm{mg} \mathrm{l}^{-1}\right)+\mathrm{PG}\left(0.5 \mathrm{mg} \mathrm{l}^{-1}\right)\right.$ & $2.25 \pm 0.94 \mathrm{~d}$ & $52.00 \pm 3.37 \mathrm{e}$ & $1.680 \pm 0.15 \mathrm{~cd}$ \\
\hline
\end{tabular}

Values marked with same letters are not significantly different (LSD, $\mathrm{p}<0.05)$. All the values are means of four replicates \pm SD.

IBA: Indole-3-butyric acid, BA: 6-Benzyladenin, PG: Phloroglucinol, Kin: Kinetin, GA: Gibberellic acid, NAA: 1-Naphthaleneacetic acid

The results of the present study showed that the MS medium fortified with IBA $\left(0.1 \mathrm{mg} \mathrm{l}^{-1}\right)$, NAA $(0.1$ and 1 $\left.\mathrm{mg}^{\mathrm{l}^{-1}}\right)$ and combinations of IBA $\left(0.1 \mathrm{mg} \mathrm{l}^{-1}\right)+$ PG $(1 \mathrm{mg}$ $\left.\mathrm{l}^{-1}\right)$, NAA $\left(0.1 \mathrm{mg} \mathrm{l}^{-1}\right)+$ PG $\left(1 \mathrm{mg} \mathrm{l}^{-1}\right)$ and NAA $(1 \mathrm{mg}$ $\left.\mathrm{l}^{-1}\right)+\mathrm{PG}\left(1 \mathrm{mg} \mathrm{l}^{-1}\right)$ increased the rooting response of the nodal explants relative to the MS medium alone, however, adding IBA $\left(0.5,1\right.$ and $\left.2 \mathrm{mg} \mathrm{l}^{-1}\right)$ and combination of IBA $\left(1 \mathrm{mg} \mathrm{l}^{-1}\right)+$ PG $\left(1 \mathrm{mg} \mathrm{l}^{-1}\right)$ to the MS medium reduced the rooting response compared to the MS medium alone. The highest percentage of rooting was observed in T6, T7, T10 and T11 treatments (Table 3). The results showed that different treatments applied, except for T9 treat- ment, increased the number of roots per explant. The highest and lowest number of roots per shoot were recorded in T6 (20.5 \pm 3.4 per shoot $)$ and T9 $(10.5 \pm 2.4$ per shoot) treatments, respectively (Table 3 ). The results also showed that T3, T4, T5, T6, T8, T9 and T10 treatments significantly increased the root length and T7 and T11 treatments reduced the root length compared to the MS medium alone, while there was no significant difference between control treatment and $\mathrm{T} 2$ treatment. The highest and lowest root lengths were observed in T4 $(4.95 \mathrm{~cm})$ and T7 $(0.475 \mathrm{~cm})$ treatments, respectively (Table 3$)$.

Table 3: The effect of different concentrations and combinations of growth regulators on rooting from the nodal explants of $W$. coagulans in in vitro conditions

\begin{tabular}{|c|c|c|c|}
\hline Treatments & Rooting response (\%) & Number of roots & Root length \\
\hline T1 (MS (Control)0 & $70 \pm 8 c$ & $13.0 \pm 1.2 \mathrm{de}$ & $1.925 \pm 0.22 \mathrm{~d}$ \\
\hline $\mathrm{T} 2\left(\mathrm{MS}+\mathrm{IBA}\left(0.1 \mathrm{mg} \mathrm{l}^{-1}\right)\right)$ & $80 \pm 8 b$ & $14.0 \pm 0.8 \mathrm{~d}$ & $1.925 \pm 0.22 \mathrm{~d}$ \\
\hline T3 (MS + IBA $\left.\left(0.5 \mathrm{mg} \mathrm{l}^{-1}\right)\right)$ & $50 \pm 7 \mathrm{~d}$ & $13.8 \pm 1.7 \mathrm{~d}$ & $3.150 \pm 0.29 b$ \\
\hline $\mathrm{T} 4\left(\mathrm{MS}+\mathrm{IBA}\left(1 \mathrm{mg} \mathrm{l}^{-1}\right)\right)$ & $65 \pm 6 c$ & $15.0 \pm 2.2 \mathrm{bcd}$ & $4.950 \pm 0.21 \mathrm{a}$ \\
\hline T5 (MS + IBA $\left.\left(2 \mathrm{mg} \mathrm{l}^{-1}\right)\right)$ & $65 \pm 9 c$ & $13.3 \pm 1.7 \mathrm{de}$ & $2.350 \pm 0.13 c$ \\
\hline T6 (MS + NAA $\left.\left(0.1 \mathrm{mg} \mathrm{l}^{-1}\right)\right)$ & $100 \pm 0 \mathrm{a}$ & $20.5 \pm 3.4 \mathrm{a}$ & $3.075 \pm 0.10 \mathrm{~b}$ \\
\hline T7 (MS + NAA $\left.\left(1 \mathrm{mg} \mathrm{l}^{-1}\right)\right)$ & $100 \pm 0 \mathrm{a}$ & $17.8 \pm 3.1 \mathrm{ab}$ & $0.475 \pm 0.10 \mathrm{f}$ \\
\hline $\mathrm{T} 8\left(\mathrm{MS}+\mathrm{IBA}\left(0.1 \mathrm{mg} \mathrm{l}^{-1}\right)+\mathrm{PG}\left(1 \mathrm{mg} \mathrm{l}^{-1}\right)\right)$ & $85 \pm 9 b$ & $14.3 \pm 2.5 \mathrm{~cd}$ & $2.975 \pm 0.17 b$ \\
\hline T9 $\left(\mathrm{MS}+\mathrm{IBA}\left(1 \mathrm{mg} \mathrm{l}^{-1}\right)+\mathrm{PG}\left(1 \mathrm{mg} \mathrm{l}^{-1}\right)\right)$ & $50 \pm 7 \mathrm{~d}$ & $10.5 \pm 2.4 \mathrm{e}$ & $4.900 \pm 0.18 \mathrm{a}$ \\
\hline $\mathrm{T} 10\left(\mathrm{MS}+\mathrm{NAA}\left(0.1 \mathrm{mg} \mathrm{l}^{-1}\right)+\mathrm{PG}\left(1 \mathrm{mg} \mathrm{l}^{-1}\right)\right)$ & $100 \pm 0 \mathrm{a}$ & $17.3 \pm 2.6 \mathrm{bc}$ & $3.050 \pm 0.13 b$ \\
\hline T11 (MS + NAA $\left.\left(1 \mathrm{mg} \mathrm{l}^{-1}\right)+\mathrm{PG}\left(1 \mathrm{mg} \mathrm{l}^{-1}\right)\right)$ & $100 \pm 0 \mathrm{a}$ & $15.5 \pm 1.7 \mathrm{bcd}$ & $1.050 \pm 0.13 \mathrm{e}$ \\
\hline
\end{tabular}

Values marked with same letters are not significantly different (LSD, $p<0.05)$. All the values are means of four replicates \pm SD.

IBA: Indole-3-butyric acid, BA: 6-Benzyladenin, PG: Phloroglucinol, Kin: Kinetin, GA: Gibberellic acid, NAA: 1-Naphthaleneacetic acid 
For acclimatization, the plantlets from the rooting experiment were transferred to pots. The results showed that the highest acclimatization was observed in T6, T7 and $\mathrm{T} 10$ treatments by 86,75 and $72 \%$, respectively. The lowest acclimatization was recorded in $\mathrm{T} 9$ and $\mathrm{T} 3$ treatments by $36 \%$ and $53 \%$, respectively (Fig. 2).

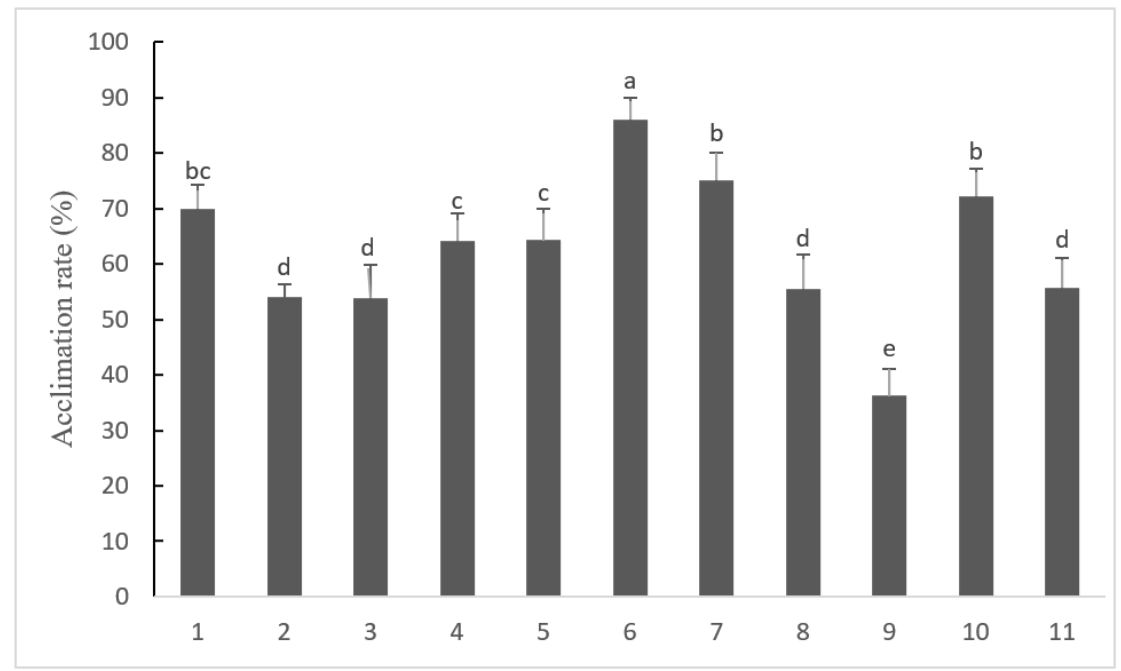

Fig. 2: The rate of hardened plants from well-rooted plantlets obtained from the second experiment (rooting experiment). Values marked with same letters are not significantly different (LSD, $p<0.05)$.

\section{DISCUSSION}

The populations of $W$. coagulans are in their natural habitat in Iran in danger of extinction due to the weak seed setting and germination created by its poor reproductive system. Irregular and uncontrolled collection of $W$. coagulans for medicinal purposes is another reason for the extinction of $W$. coagulans in Iran. In order to prevent the disappearance of the local $W$. coagulans populations, it is therefore necessary to take timely measures for their conservation (Gilani et al., 2009). Since there are many limitations (low seed viability and self-incompatibility) to conventional propagation of $W$. coagulans plants, in vitro culture can be effective in the propagation of genetically uniform plants in large numbers (Valizadeh \& Valizadeh, 2011). Induction of rooting, elongation of micro-shoots, differentiation and development of stem buds in $W$. coagulans plants under different concentrations and combinations of plant growth regulators are different. The results of the present study showed that the highest induction of shooting and shoot length was obtained in the MS + IBA $\left(0.01 \mathrm{mg} \mathrm{l}^{-1}\right)+\mathrm{BA}\left(0.5 \mathrm{mg} \mathrm{l}^{-1}\right)+$ PG $\left(0.5 \mathrm{mg} \mathrm{l}^{-1}\right)+\mathrm{GA}\left(0.5 \mathrm{mg} \mathrm{l}^{-1}\right)$ treatment compared to other treatments. Saritha \& Naidu (2007) indicated that
MS media fortified with $0.1 \mathrm{mg} \mathrm{l}^{-1} \alpha$-naphthalene acetic acid $\left(1.5 \mathrm{mg} \mathrm{l}^{-1}\right)$ and $2 \mathrm{mg} \mathrm{l}^{-1} \mathrm{BA}\left(1.5 \mathrm{mg} \mathrm{l}^{-1}\right)$ was the best treatment to induce shooting of $W$. somnifera from axillary buds. In another report, Jain et al. (2011) showed that the multiple adventitious shoots of $W$. coagulans plant were differentiated in the MS medium containing BA (5 $\left.\mathrm{mg} \mathrm{l}^{-1}\right)$ and kinetin $\left(0.5 \mathrm{mg} \mathrm{l}^{-1}\right)$ from leaf explants. Rathore et al. (2016) studied the effect of different concentrations of plant hormones (6-Benzylaminopurine (BAP), Kin and TDZ) on shoot regeneration from leaf explant of $W$. coagulans and showed that the highest shoot regeneration (74\%) was observed under $1 \mathrm{mg} \mathrm{l}^{-}$ ${ }^{1}$ BAP treatment. The effect of different concentrations and combinations of growth regulators on the callus induction from the nodal explants of $W$. coagulans was performed by Valizadeh \& Valizadeh (2009), who indicated that the highest growth of callus was observed on the MS medium supplemented with BA $\left(0.25 \mathrm{mg} \mathrm{l}^{-1}\right)$ and 2, 4-D $\left(4 \mathrm{mg} \mathrm{l}^{-1}\right)$. PG is an important phenolic compound that effectively induces the growth of root and shoot in stem culture. The results of the present study showed that PG had a positive effect on the shooting and shoot length, and the similar results have been reported on the effect of PG on shoot multiplication on Minuartia valentina 
(Pau) Sennen by Ibanez \& Amo-Marc (1998). Our findings confirmed that the highest shoot multiplication and shooting were achieved on the MS medium containing $\mathrm{MS}+\mathrm{IBA}\left(0.01 \mathrm{mg} \mathrm{l}^{-1}\right)+\mathrm{BA}\left(0.5 \mathrm{mg} \mathrm{l}^{-1}\right)+\mathrm{PG}\left(0.5 \mathrm{mg} \mathrm{l}^{-1}\right)$ $+\mathrm{GA}\left(0.5 \mathrm{mg} \mathrm{l}^{-1}\right)$, which can be considered in the propagation of $W$. coagulans medicinal plant.

Auxin has been reported to induce lateral rooting and improve primordium growth (Rathore et al., 2016). The results of the present study showed that NAA was more effective in rooting and number of roots than IBA. Valizadeh \& Valizadeh (2011) investigated the effect of different concentrations of IBA, auxin and Kin on rooting of $W$. coagulans and showed that the highest percentage of rooting and number of roots were obtained under the IBA $\left(2 \mathrm{mg} \mathrm{l}^{-1}\right)$ treatment. NAA-induced rooting has also been reported in other medicinal plants (Ahmed et al., 2007b; Sivansean \& Murugesan, 2008). In another report, Ahmed et al. (2007a) indicated that auxin and NAA treatments induced the highest rate of rooting in stevia plant in in vitro condition. In general, various studies have shown that various auxin hormones are effective in inducing rooting in in vitro conditions. Different effects by some compounds can be due to differences in plant species, genotype, age and physiological status of the mother plants. The results also showed that adding PG to the MS medium containing IBA or NAA reduced number of roots compared to IBA and NAA treatments alone, indicating a negative effect of $\mathrm{PG}$ on rooting induction.

\section{CONCLUSION}

In summary, the results of the present study showed that the nodal explants of $W$. coagulans have a high organogenic potential for rooting and shooting response, however, the concentration and combination of growth regulators have a significant effect on rooting and shooting rate. Our findings highlight a complete propagation method for $W$. coagulans plants from the nodal explant that can also be used in genetic transformation studies to improve the plant and protect plant from extinction.

\section{REFERENCES}

Ahmed, M. B., Salahin, M., Karim, R., Razvy, M. A., Hannan, M. M., Sultana, R., Hossain, M., \& Islam, R. (2007a). An efficient method for in vitro clonal propagation of a newly introduced sweetener plant (Stevia rebaudiana Bertoni.) in Bangladesh. American-Eurasian Journal of Scientific Research, 2(2), 121-125.

Ahmed, S., Kabir, A. H., Ahmed, M. B., Razvy, M. A., \& Ganesan, S. (2007b). Development of rapid micro- propagation method of Aloe vera L. Sjemenarstvo, 24, $121-128$

Chen, L. X., He, H., \& Qui, F. (2011). Natural withanolides: an overview. Nature Product Reports, 28, 705740. https://doi.org/10.1039/c0np00045k

Gerami, M., Ghorbani, A., \& Karimi, S. (2018). Role of salicylic acid pretreatment in alleviating cadmiuminduced toxicity in Salvia officinalis L. Iranian Journal of Plant Biology, 10(1), 81-95.

Ghasemi-Omran VO, Ghorbani A, Sajjadi-Otaghsara SA (2021) Melatonin alleviates $\mathrm{NaCl}$-induced damage by regulating ionic homeostasis, antioxidant system, redox homeostasis, and expression of steviol glycosides-related biosynthetic genes in in vitro cultured Stevia rebaudiana Bertoni. In Vitro Cell Dev Biol.Plant. https://doi.org/10.1007/s11627-021-10161-9 https://doi.org/10.1007/s11627-021-10161-9

Ghorbani, A., Ghasemi Omran, V. O., Razavi, S. M., Pirdashti, H., \& Ranjbar, M. (2019). Piriformospora indica confers salinity tolerance on tomato (Lycopersicon esculentum Mill.) through amelioration of nutrient accumulation, $\mathrm{K}^{+/} \mathrm{Na}^{+}$homeostasis and water status. Plant Cell Reports, 38, 1151-1163. https://doi. org/10.1007/s00299-019-02434-w

Ghorbani, A., Razavi, S. M., Ghasemi Omran, V. O., \& Pirdashti, H. (2018). Piriformospora indica inoculation alleviates the adverse effect of $\mathrm{NaCl}$ stress on growth, gas exchange and chlorophyll fluorescence in tomato (Solanum lycopersicum L.). Plant Biology, 20(4), 729-736. https://doi.org/10.1111/plb.12717

Gilani, S. A., Kikuchi, A., \& Watanabe, K. N. (2009). Genetic variation within and among fragmented populations of endangered medicinal plant, Withania coagulans (Solanaceae) from Pakistan and its implications for conservation. African Journal of Biotechnology, 8, 2948-2958.

Haq, I., Youn, U. J., Chai, X., Park, E. J., Kondratyuk, T. P., Simmons, C. J., Borris, R. P., Mirza, B., Pezzuto, J. M., \& Chang, L. C., (2013). Biologically active withanolides from Withania coagulans. Journal of Natural Products, 76, 22-28. https://doi.org/10.1021/ np300534x

Ibanez, M. R., \& Amo-Marc, J. B. (1998). Promotion by phloroglucinol of micropropagation of Minuartia valentina, an endangered and endemic Spanish plant. Plant Growth Regulators, 26, 49-56. https://doi. org/10.1023/A:1006050122173

Jain, R., Sinha, A., Jain, D., Kachhwaha, S., \& Kothari, S. L. (2010). Adevntitious shoot regeneration and in vitro biosynthesis of steroidal lactones in Withania Coagulans (Stocks) Dunal. Plant Cell, Tissue and Organ Culture, 105, 135-140 https://doi.org/10.1007/ s11240-010-9840-3 
Maurya, R., \& Akanksha, J. (2010). Chemistry and pharmacology of Withania coagulans: an ayurvedic remedy. Journal of Pharmacy and Pharmacology, 62, 153160. https://doi.org/10.1211/jpp.62.02.0001

Rathore, M. S., Mastan, S. G., Yadav, P., Bhatt, V. D., Shekhawat, N. S., \& Chikara, J. (2016). Shoot regeneration from leaf explants of Withania coagulans (Stocks) Dunal and genetic stability evaluation of regenerates with RAPD and ISSR markers. South African Journal of Botany, 102, 12-17. https://doi.org/10.1016/j. sajb.2015.08.003

Rathore, M. S., Shekhawat, S., Kaur, G., Singh, R. P., \& Shekhawat, N. S. (2012). Micropropagation of vegetable rennet (Withania coagulans [Stocks] Dunal)-a critically endangered medicinal plant. Journal of Sustainable Forestry, 31, 727-746. https://doi.org/10.108 0/10549811.2012.706533
Saritha, K. V., \& Naidu, C. V. (2007). In vitro flowering of Withania somnifera Dunal. -An important antitumor medicinal plant. Plant Science, 172, 847-851. https:// doi.org/10.1016/j.plantsci.2006.12.016

Sivansean, I., \& Murugesan, K. (2008). An efficient regeneration from nodal explants of Withania somnifera Dunal. Asian Journal of Plant Sciences, 7(6), 551- 556. https://doi.org/10.3923/ajps.2008.551.556

Valizadeh, J., \& Valizadeh, M. (2009). In vitro callus induction and plant regeneration from Withania coagulans: A valuable medicinal plant. Pakistan Journal of Biological Sciences, 12(21), 1415-1419. https://doi. org/10.3923/pjbs.2009.1415.1419

Valizadeh, J., \& Valizadeh, M. (2011). Development of efficient micropropagation protocol for Withania coagulans (Stocks) Dunal. African Journal of Biotechnology, 10(39), 7611-7616. 